\title{
USE OF THE EFFECTIVE HEAT OF FORMATION RULE FOR PREDICTING PHASE FORMATION SEQUENCE IN AI-Ni SYSTEMS
}

\author{
R. PRETORIUS \\ Van de Graaff Group, National Accelerator Centre, Faure 7131, South Africa \\ R. DE REUS, A.M. VREDENBERG and F.W. SARIS \\ FOM-Institute for Atomic and Molecular Physics, Kruislaan 407, 1098 SJ Amsterdam. The Netherlands
}

Received 4 May 1990

\begin{abstract}
The effective heat of formation $\left(\Delta H^{\prime}\right)$ of any compound can be calculated as a function of the concentration of its components. By using this concept in conjunction with the lowest eutectic of the $\mathrm{Al}-\mathrm{Ni}$ system, first phase formation and phase sequence has been successfully predicted for $\mathrm{Al} / \mathrm{Ni}, \mathrm{Al} / \mathrm{Ni}_{3} \mathrm{Al}, \mathrm{Ni} / \mathrm{NiAl}_{3}, \mathrm{NiAl}_{3} / \mathrm{Ni}_{3} \mathrm{Al}$ and $\mathrm{Al} / \mathrm{NiAl} / \mathrm{Ni}$ structures.
\end{abstract}

\section{Introduction}

There has been considerable interest in the formation of thin-film intermetallic aluminide compounds as aluminium is frequently used in metallizations for integrated circuits. An excellent summary of research carried out on thin-film aluminides is given in the thesis by Colgan [1]. The Al-Ni system in particular has enjoyed considerable interest [2-8]. These investigations show that in thin-film bilayers of nickel and aluminium, $\mathrm{NiAl}_{3}$ is the first compound phase to form at temperatures around 250 $275^{\circ} \mathrm{C}$, while marker experiments identify $\mathrm{Al}$ as the dominant diffusing species [7]. In the case of excess nickel (thin $\mathrm{Al}$ on thick $\mathrm{Ni}$ ) $\mathrm{Ni}_{2} \mathrm{Al}_{3}$ is the next phase to form after all the $\mathrm{Al}$ has been consumed, followed by phases increasingly rich in Ni namely NiAl and $\mathrm{Ni}_{3} \mathrm{Al}$ [6]. All four of the intermetallic phases given in the phase diagram thus grow sequentially, unlike silicide formation where the non-congruent phases are skipped [9-11]. Colgan et al. [5] tried to predict initial phase formation and phase sequence in $\mathrm{Al} / \mathrm{Ni}, \mathrm{Al} / \mathrm{NiAl} / \mathrm{Ni}, \mathrm{Al} / \mathrm{Ni}_{3} \mathrm{Al}, \mathrm{NiAl}_{3} / \mathrm{Ni}_{3} \mathrm{Al}$ and $\mathrm{Ni} /$ $\mathrm{NiAl}_{3}$ thin-film structures, by using thermodynamic considerations (common tangent rule). These effects were unsuccessful for all the structures and it was concluded that the thermodynamic forces seem unrelated to phase sequence [5].
Recently, the concept of an effective heat of formation $\left(\Delta H^{\prime}\right)$ was formulated and used in conjunction with the lowest eutectic of the binary system to successfully predict silicide phase sequence in metalsilicon systems $[12,13]$. The effective heat of formation rule was also used to explain how the presence of impurities such as oxygen or small amounts of Au can alter phase formation sequence during nickel and cobalt silicide formation respectively [13]. In the present work the effective heat of formation rule is formulated for the first time for metal-metal interaction and used for prediction of phase formation sequence in $\mathrm{Al}-\mathrm{Ni}$ systems.

\section{Effective heat of formation concept}

The change in enthalpy (or heat of formation) $\Delta H^{0}$ is a good measure of the change in free energy $\Delta G^{0}$ because the change in entropy $\Delta S^{0}$ is usually very small during solid-state interaction. It should thus therefore be feasible to use heats of formation to predict phase formation in those cases where activation or nucleation barriers do not exist as the system would always want to go to its lowest possible free energy state. From the heats of formation for the different aluminide phases (see table 1) which can form in the $\mathrm{Al} / \mathrm{Ni}$ binary system, it can be seen that $\mathrm{Ni}_{2} \mathrm{Al}_{3}$ 
Table 1

Standard heats of formation for nickel-aluminide compounds [14]

\begin{tabular}{lll}
\hline Phase & $\begin{array}{l}\Delta H^{0} \\
(\mathrm{~kJ} / \mathrm{g} \mathrm{mol})\end{array}$ & $\begin{array}{l}\Delta H^{0} \\
(\mathrm{~kJ} / \mathrm{g} \text { at })\end{array}$ \\
\hline $\mathrm{NiAl}_{3}$ & -152 & -38 \\
$\mathrm{Ni}_{2} \mathrm{Al}_{3}$ & -285 & -57 \\
$\mathrm{NiAl}$ & -118 & -59 \\
$\mathrm{Ni}$ & -164 & -41 \\
\hline
\end{tabular}

has the most negative heat of formation namely $-285 \mathrm{~kJ} / \mathrm{g}$ mol. Yet, $\mathrm{Ni}_{2} \mathrm{Al}_{3}$ is not the first phase to form during $\mathrm{Ni}-\mathrm{Al}$ solid-state interaction [2-8]. It is clear that the reason why $\mathrm{Ni}_{2} \mathrm{Al}_{3}$ has the most negative heat of formation when expressed as $\mathrm{kJ} / \mathrm{g} \mathrm{mol}$, is because it has the most atoms and therefore the most bonds per empirical formula. This artifact can be accounted for by expressing heats of formation in terms of $\mathrm{kJ} / \mathrm{g}$ at (the heat of formation in $\mathrm{kJ} / \mathrm{g}$ mol divided by the number of atoms in the compound), which is the heat released when the total number of $\mathrm{Ni}$ and $\mathrm{Al}$ atoms involved in forming the compound is equal to Avogadro's number. The compound NiAl now has the most negative heat of formation (see table 1) and its formation would be expected to lead to the lowest free energy state for the system. This does however still not agree with experimental observations and it is clear that other factors have to be considered.

During solid-state interaction in thin-film structures phase formation at an interface is a non-equilibrium process. In the case of silicide formation for instance, it is always found that only one compound phase forms at a particular interface [9], which is unlike equilibrium systems where simultaneous formation of a mixture of phases can lead to the lowest free energy state. In the effective heat of formation concept single phase formation and the concentrations of the reacting species are taken into account when considering the free energy change of the system during interaction $[12,13]$. Let us consider for example the interaction between $\mathrm{Ni}$ and $\mathrm{Al}$ to form the phase $\mathrm{Ni}_{2} \mathrm{Al}_{3}\left(\mathrm{Ni}_{0.40} \mathrm{Al}_{0.60}\right)$. If (for illustration purposes only) a situation exists where the effective concentration of $\mathrm{Ni}$ at the growth interface is 70 at.\% and $\mathrm{Al}$ is 30 at.\% $\left(\mathrm{Ni}_{0.70} \mathrm{Al}_{0.30}\right)$, it is clear that $\mathrm{Al}$ is the limiting element. All the $\mathrm{Al}$ atoms will react dur- ing the formation of $\mathrm{Ni}_{2} \mathrm{Al}_{3}$, while the excess $\mathrm{Ni}$ atoms will not. If we consider a total number of $\mathrm{Ni}$ and $\mathrm{Al}$ atoms equal to Avogadro's number $N_{\mathrm{A}}$, the total amount of heat released by the system will be 28.5 $\mathrm{kJ}(57 \mathrm{~kJ} \times 0.30 / 0.60)$. All the $\mathrm{Al}$ atoms are used up to form $\mathrm{Ni}_{2} \mathrm{Al}_{3}$ while $(0.70-0.40 \times 0.30 / 0.60) N_{\mathrm{A}}$ atoms of $\mathrm{Ni}$ will be in "excess". It should however be pointed out that phase formation at a growth interface is a dynamic non-equilibrium process and the "excess" atoms can be looked upon as being available for formation of the next increment of compound at the moving interface. It can thus be seen that the heat released is dictated by the available concentration of the limiting element and the concentration of the limiting element in the compound to be formed. An effective heat of formation $\Delta H^{\prime}$ can therefore be defined as:

$$
\begin{aligned}
& \Delta H^{\prime}=\Delta H^{0} \\
& \times \frac{\text { effective concentration limiting element }}{\text { compound concentration limiting element }},
\end{aligned}
$$

where $\Delta H^{0}$ is the heat of formation in $\mathrm{kJ}$ per $\mathrm{g}$ at. By using this equation the effective heat of formation $\left(\Delta H^{\prime}\right)$ of all the known nickel-aluminide phases can be calculated as a function of concentration of the reacting species. The effective heats of formation for the nickel-aluminium compounds calculated at two different concentrations are given in table 2. It can be seen that for an effective concentration of 70 atom $\% \mathrm{Ni}$ and 30 atom $\% \mathrm{Al}$ at a given growth interface the formation of $\mathrm{Ni}_{3} \mathrm{Al}$ has the most negative effective heat of formation namely $-38.3 \mathrm{~kJ} / \mathrm{g}$ at. Formation of this phase is thus expected to take place under these conditions, since by doing so, the system will be in its lowest free energy state. If a situation however exists at the growth interface where there is a much higher concentration of aluminium atoms ( 96.5 atom \%) we see now from table 2 that the formation of the $\mathrm{NiAl}_{3}$ phase will lead to the greatest free energy change as it has the most negative $\Delta H^{\prime}$ namely $-5.3 \mathrm{~kJ} / \mathrm{g}$ at. Such calculations can be represented graphically and the effective heat of formation diagram for the $\mathrm{Ni}-\mathrm{Al}$ system, together with its phase diagram is given in fig. 1. For each phase the most negative $\Delta H^{\prime}$ and thus the release of the most energy from the system occurs when the $\mathrm{Ni}$ and 
Table 2

The effective heats of formation $\left(\Delta H^{\prime}\right)$ of nickel-aluminide compounds, calculated at two different available (effective) concentrations of the reacting elements. The second set of $\Delta H^{\prime}$ values are calculated at the composition of the lowest melting eutectic of the $\mathrm{Ni}-\mathrm{Al}$ binary system ( 3.5 atom $\% \mathrm{Ni}, 96.5$ atom $\% \mathrm{Al}$ )

\begin{tabular}{|c|c|c|c|c|c|}
\hline \multirow[t]{3}{*}{ Phase } & \multirow{3}{*}{$\begin{array}{l}\text { Compound } \\
\text { concentration }\end{array}$} & \multicolumn{4}{|c|}{ Available concentration } \\
\hline & & \multicolumn{2}{|c|}{$\mathrm{Ni}_{0.700} \mathrm{Al}_{0.300}$} & \multicolumn{2}{|c|}{$\mathrm{Ni}_{0.035} \mathrm{Al}_{0.965}$} \\
\hline & & $\begin{array}{l}\text { limiting } \\
\text { element }\end{array}$ & $\begin{array}{l}\Delta H^{\prime} \\
(\mathrm{kJ} / \mathrm{g} \text { at })\end{array}$ & $\begin{array}{l}\text { limiting } \\
\text { element }\end{array}$ & $\begin{array}{l}\Delta H^{\prime} \\
\text { (kJ/g at) }\end{array}$ \\
\hline $\mathrm{NiAl}_{3}$ & $\left(\mathrm{Ni}_{0.25} \mathrm{Al}_{0.75}\right)$ & $\mathrm{Al}$ & -15.2 & $\mathrm{Ni}$ & -5.3 \\
\hline $\mathrm{Ni}_{2} \mathrm{Al}_{3}$ & $\left(\mathrm{Ni}_{0.40} \mathrm{Al}_{0.60}\right)$ & $\mathrm{Al}$ & -28.5 & $\mathrm{Ni}$ & -4.9 \\
\hline $\mathrm{NiAl}$ & $\left(\mathrm{Ni}_{0.50} \mathrm{Al}_{0.50}\right)$ & $\mathrm{Al}$ & -35.4 & $\mathrm{Ni}$ & -4.1 \\
\hline $\mathrm{Ni}_{3} \mathrm{Al}$ & $\left(\mathrm{Ni}_{0.75} \mathrm{Al}_{0.25}\right)$ & $\mathrm{Ni}$ & -38.3 & $\mathrm{Ni}$ & -1.9 \\
\hline
\end{tabular}

Al concentrations match that of the composition of a particular compound. Then the ratio of the effective concentration and compound concentration is unity (see eq. (1)) and $\Delta H^{\prime}$ is thus equal to $\Delta H^{0}$. Effective heats of formation diagrams can thus be readily constructed by plotting the heats of formation $\Delta H^{0}$ (expressed in $\mathrm{kJ} / \mathrm{g}$ at) of each compound in the binary system at its compositional concentration and completing the triangulation by connecting to the end points of the concentration axis.

\section{First phase formation}

The question now arises, what will the effective concentrations be of $\mathrm{Ni}$ and $\mathrm{Al}$ atoms at the reacting interface of a $\mathrm{Ni}-\mathrm{Al}$ couple during heating? It is important first of all to emphasize that unlike the case for equilibrium phase diagrams, thin-film solid-state interaction is a non-equilibrium process and the effective concentrations at the growth interface are independent of the relative thicknesses of the interacting components. Many factors could influence the actual number of $\mathrm{Ni}$ and $\mathrm{Al}$ atoms which are available to interact. This is why the term effective concentration is used in the effective heat of formation concept. Brown and Ashby [15] have however shown that the activation energy for solid-state diffusion is directly proportional to the melting point of the solid, while it is well known that solid phase sintering in metallic alloys occurs at the Tamman temperature [16]. The greatest mobility of the atoms and therefore the most effective mixing at the interface upon heating, is thus expected to take place at the composition of the lowest eutectic of the Ni-Al phase diagram. We therefore choose the effective concentrations of the interacting atoms to be that of the lowest eutectic, which is also the composition used in the Walser-Bené phase formation rule [10]. This composition is indicated by the arrow in the effective heat of formation diagram for the $\mathrm{Ni}-\mathrm{Al}$ system (fig. 1, top). In the last column of table 2 the effective heats of formation $\left(\Delta H^{\prime}\right)$ values of all four of the compound phases have been calculated at the lowest eutectic concentration (3.5 atom \% Ni, 96.5 atom $\% \mathrm{Al}$ ). The value of $-5.3 \mathrm{~kJ} / \mathrm{g}$ at for $\mathrm{NiAl}_{3}$ is the most negative and it is thus expected to be the first to form, which is in agreement with experimental observations [2-8]. A rule for the first phase formation can thus be formulated, which states: The first compound phase to form during metal-metal interaction is the phase with the most negative effective heat of formation $\left(\Delta H^{\prime}\right)$ at the concentration of the lowest temperature eutectic of the binary system.

\section{Phase sequence}

For the case of a thin $\mathrm{Al}$ film on thick $\mathrm{Ni}(\mathrm{Al}<\mathrm{Ni})$ a stage will be reached during interaction where all the aluminium will be consumed during first phase $\mathrm{NiAl}_{3}$ formation. At this point the effective concentration of $\mathrm{Al}$ at the growth interface is expected to decrease and the relative concentrations move to the right of the effective heat of formation diagram reaching a value of about 73 atom $\% \mathrm{Al}$ and 27 atom 


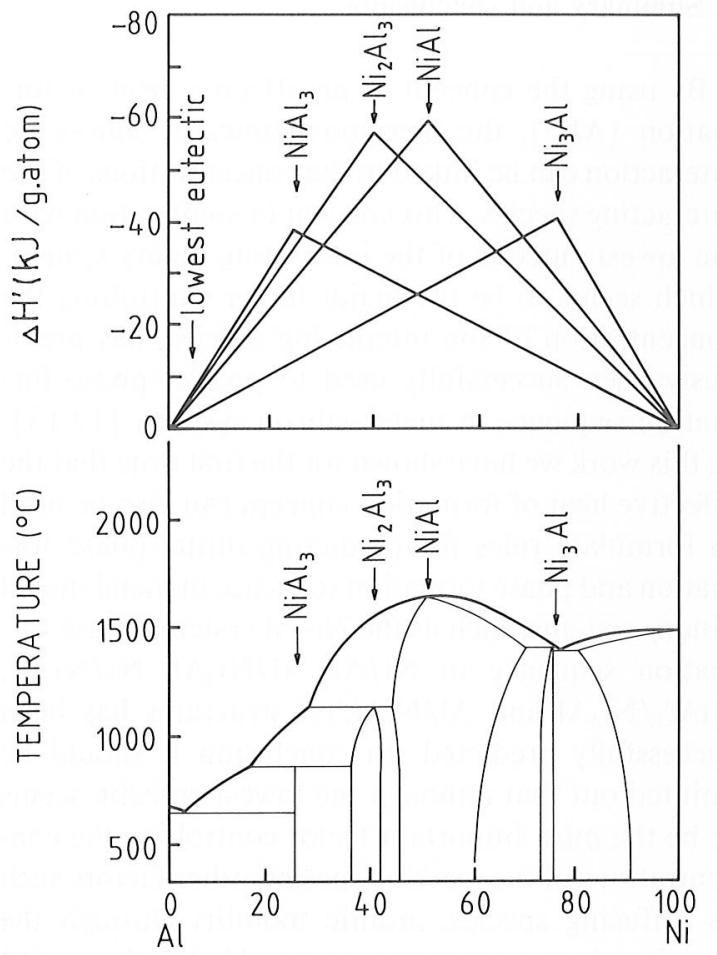

ATOMIC \%Ni

Fig. 1. The effective heat of formation $\left(\Delta H^{\prime}\right)$ diagram for compound phase formation (top) and the phase diagram (bottom) for the Ni-Al system. Each triangle of the effective heat of formation diagram represents the energy released during formation of a particular nickel-aluminide compound phase, as a function of concentration. The most negative effective heat of formation $\left(\Delta H^{\prime}\right)$ occurs when the $\mathrm{Ni}$ and $\mathrm{Al}$ concentrations match that of the composition of a particular compound as the ratio of the effective concentration and compound concentration is unity and $\Delta H^{\prime}$ is thus equal to $\Delta H^{0}$ (see eq. (1)).

$\% \mathrm{Ni}$ (see fig. 1) where $\mathrm{Ni}_{2} \mathrm{Al}_{3}$ formation should lead to the most negative effective heat of formation. After transformation of $\mathrm{NiAl}_{3}$ to $\mathrm{Ni}_{2} \mathrm{Al}_{3}$ the effective concentration of the atoms at the $\mathrm{Ni} / \mathrm{Ni}_{2} \mathrm{Al}_{3}$ interface moves further to the right (nickel-rich direction) until NiAl formation becomes the most likely phase to form. After complete transformation to $\mathrm{NiAl}$, the effective concentration again moves to the Ni-rich direction and $\mathrm{Ni}_{3} \mathrm{Al}$ starts to form at the $\mathrm{Ni} / \mathrm{NiAl}$ interface. After all the $\mathrm{NiAl}$ has been transformed to $\mathrm{Ni}_{3} \mathrm{Al}$ no further reaction with $\mathrm{Ni}$ takes place as no other phases exist which are more nickel rich. An effective heat of formation rule for phase sequence can thus be formulated: After first-phase formation in metal-metal binary systems, the next phase to form at the interface between the compound phase and remaining element is the next phase richer in the unreacted element, which has the most negative effective heat of formation. It has to be pointed out that unlike metal-silicon systems this rule includes all phases, because the non-congruent phases are apparently not skipped in metal-metal systems.

The effective heat of formation rule therefore predicts that for thin $\mathrm{Al}$ films on thick $\mathrm{Ni}(\mathrm{Al}<\mathrm{Ni})$, the first phase which forms is $\mathrm{NiAl}_{3}$, followed by $\mathrm{Ni}_{2} \mathrm{Al}_{3}$, $\mathrm{NiAl}$ and $\mathrm{Ni}_{3} \mathrm{Al}$. This is in complete agreement with experiment [6]. For thin films and thick $\mathrm{Al}(\mathrm{Ni}<\mathrm{Al})$ $\mathrm{NiAl}_{3}$ will again be the first phase to form. When all the $\mathrm{Ni}$ is consumed the effective concentration of $\mathrm{Al}$ will tend to move to values greater than the composition of $\mathrm{NiAl}_{3}$ but as no further phases richer in $\mathrm{Al}$ exist no interaction is expected to take place and $\mathrm{NiAl}_{3}$ is the first and only phase to form.

\section{Decomposition}

Apart from Ni-Al couples, Colgan et al. also measured phase formation and decomposition in $\mathrm{Al} /$ $\mathrm{Ni}_{3} \mathrm{Al}, \mathrm{Ni} / \mathrm{NiAl}_{3}, \mathrm{NiAl}_{3} / \mathrm{Ni}_{3} \mathrm{Al}$ and $\mathrm{Al} / \mathrm{NiAl} / \mathrm{Ni}$ structures [5], the results of which can be used to test the effective heat of formation rule and see whether it also holds for these cases. During heating of the $\mathrm{Al} / \mathrm{Ni}_{3} \mathrm{Al}$ structure, mixing at the interface is again expected to take place at the concentration of the lowest eutectic for the Ni-Al binary system (see fig. 1). At this effective concentration $\mathrm{NiAl}_{3}$ is again expected to be the first phase to form as was the case for the $\mathrm{Ni} / \mathrm{Al}$ system. For $\mathrm{Ni} / \mathrm{NiAl}_{3}$ we have the same situation as for thin $\mathrm{Al}$ on thick $\mathrm{Ni}$, after all the aluminium has been consumed during first phase $\mathrm{NiAl}_{3}$ formation. According to the effective heat of formation rule the phase formed will be the next phase richer in the unreacted element $(\mathrm{Ni})$, which has the most negative effective heat of formation. From fig. 1 we see that $\mathrm{Ni}_{2} \mathrm{Al}_{3}$ is expected to form at the $\mathrm{Ni}$ / $\mathrm{NiAl}_{3}$ interface. For the $\mathrm{NiAl}_{3} / \mathrm{Ni}_{3} \mathrm{Al}$ structure the effective concentration at the interface is according to our rule controlled by the lowest eutectic on the Al side of the phase diagram. No free $\mathrm{Al}$ is available so the next phase more nickel rich than $\mathrm{NiAl}_{3}$ will 
form, which is $\mathrm{Ni}_{2} \mathrm{Al}_{3}$. When an $\mathrm{Al} / \mathrm{NiAl} / \mathrm{Ni}$ structure is heated, the lowest eutectic of the $\mathrm{Al} / \mathrm{Ni}$ system being at 96.5 atom \% $\mathrm{Al}$ will again lead to mixing at this concentration at the $\mathrm{Al} / \mathrm{NiAl}$ interface leading to $\mathrm{NiAl}_{3}$ formation. At the $\mathrm{NiAl} / \mathrm{Ni}$ interface the only phase which can form is $\mathrm{Ni}_{3} \mathrm{Al}$, however, its reaction rate is expected to be much slower, as the interface composition is further away from the lowest eutectic and less mobility of the atoms can thus be expected. In summary, whatever the configuration of a specific sample, mixing at the interface(s) will always be controlled by the lowest temperature eutectic of the $\mathrm{Ni}-\mathrm{Al}$ binary system and the effective concentrations of $\mathrm{Ni}$ and $\mathrm{Al}$ will be expected to be that of the eutectic composition. This is expected to be so even if the eutectic composition does not lie between the compositions of the interacting phases. Phases will always react with each other to form the most Al-rich phase with a composition lying between that of the interacting phases. Reaction to form a phase outside this composition range can only lead to an increase in free energy, as it leads to less bond formation.

In table 3 the results are summarized and compared with the experimental measurements of Colgan et al. [5]. It can be seen that in every case the effective heat of formation rule $\left(\Delta H^{\prime}\right)$ correctly predicts the initial phase formation. This is in contrast to the efforts by Colgan et al., who also used thermodynamics to predict phase formation and decomposition in these structures [5], but in none of the cases (see second column of table 3 ) is their prediction successful.

Table 3

Predicted and observed first phase compound formation for various structures in the $\mathrm{Ni}-\mathrm{Al}$ binary system ${ }^{\text {a) }}$

\begin{tabular}{|c|c|c|c|}
\hline \multirow[t]{2}{*}{ Sample } & \multicolumn{2}{|c|}{ Predicted } & \multirow{2}{*}{$\begin{array}{l}\text { Experimentally } \\
\text { observed }\end{array}$} \\
\hline & Colgan & $\Delta H^{\prime}$ & \\
\hline $\mathrm{Ni} / \mathrm{Al}$ & $\mathrm{NiAl}$ & $\mathrm{NiAl}_{3}$ & $\mathrm{NiAl}_{3}$ \\
\hline $\mathrm{Al} / \mathrm{Ni}_{3} \mathrm{Al}$ & $\mathrm{NiAl}$ & $\mathrm{NiAl}_{3}$ & $\mathrm{NiAl}_{3}$ \\
\hline $\mathrm{Ni} / \mathrm{NiAl}_{3}$ & $\mathrm{Ni}_{3} \mathrm{Al}$ & $\mathrm{Ni}_{2} \mathrm{Al}_{3}$ & $\mathrm{Ni}_{2} \mathrm{Al}_{3}$ \\
\hline $\mathrm{NiAl}_{3} / \mathrm{Ni}_{3} \mathrm{Al}$ & $\mathrm{NiAl}$ & $\mathrm{Ni}_{2} \mathrm{Al}_{3}$ & $\mathrm{Ni}_{2} \mathrm{Al}_{3}$ \\
\hline $\mathrm{Al} / \mathrm{NiAl} / \mathrm{Ni}$ & $\mathrm{Ni}_{3} \mathrm{Al}$ & $\mathrm{NiAl}_{3}$ & $\mathrm{NiAl}_{3}$ \\
\hline
\end{tabular}

a) Phases predicted by Colgan et al. [5] compared to those predicted by the effective heat of formation $\left(\Delta H^{\prime}\right)$ rule. The experimentally observed phases are also from ref. [5].

\section{Summary and conclusions}

By using the concept of an effective heat of formation $\left(\Delta H^{\prime}\right)$, the thermodynamics of solid-state interaction can be linked to the concentrations of the interacting species. This concept in conjunction with the lowest eutectic of the interacting binary system, which seems to be the major factor controlling the concentration of the interacting species, has previously been successfully used to predict phase formation sequence in metal-silicon systems [12,13]. In this work we have shown for the first time that the effective heat of formation concept can also be used to formulate rules for predicting initial phase formation and phase formation sequence in metal-metal binary systems, such as the Ni-Al system. Phase formation sequence in $\mathrm{Ni} / \mathrm{Al}, \mathrm{Al} / \mathrm{Ni}_{3} \mathrm{Al}, \mathrm{Ni} / \mathrm{NiAl}_{3}$, $\mathrm{NiAl}_{3} / \mathrm{Ni}_{3} \mathrm{Al}$ and $\mathrm{Al} / \mathrm{NiAl} / \mathrm{Ni}$ structures has been successfully predicted. In conclusion it should be pointed out that although the lowest eutectic seems to be the most important factor controlling the concentrations of the reacting species, other factors such as diffusing species, atomic mobility through the growing phase, impurities, etc., could also play a role, especially in those cases where the lowest eutectic is not very pronounced. The effective heat of formation concept therefore provides a link between thermodynamics and kinetics.

\section{Acknowledgement}

One of us (RP) would like to thank the Foundation for Research and Development of the CSIR for their financial assistance. The work at the FOMInstitute is part of the research program at FOM and was made possible by financial support from the Nederlandse Organisatie voor Wetenschappelijk Onderzoek.

\section{References}

[1] E.G. Colgan, Ph.D. Thesis, Cornell University (1987).

[2] J.E.E. Baglin and F.M. d'Heurle, in: Ion beam surface layer analysis, Vol. 1, eds. O. Meyer, G. Linker and F. Käppeler (Plenum Press, New York, 1976) p. 385. 
[3] U. Köster, P.S. Ho and M. Ran, Thin Solid Films 67 (1980) 35.

[4] M. Nastasi, L.S. Hung and J.W. Mayer, Appl. Phys. Letters 43 (1983) 831.

[5] E.G. Colgan, M. Nastasi and J.W. Mayer, J. Appl. Phys. 58 (1985) 4125.

[6] E.G. Colgan and J.W. Mayer, in: Thin films - interfaces and phenomena, eds. R.J. Nemanich, P.S. Ho and S. S. Lau (North-Holland, Amsterdam, 1986) p. 121.

[7] E.G. Colgan and J.W. Mayer, Nucl. Instr. Methods B 17 (1986) 242.

[8] E.G. Colgan and J.W. Mayer, J. Mater. Res. 1 (1986) 242.

[9] M.-A. Nicolet and S.S. Lau, in: VLSI electronics: microstructure science, Vol. 6, ed. N. Einspruch (Academic Press, New York, 1983) p. 329.
[10] R.M. Walser and R.W. Bené, Appl. Phys. Letters 28 (1976) 624.

[11 ] E.G. Colgan, B.Y. Tsaur and J.W. Mayer, Appl. Phys. Letters 37 (1981) 938.

[12] R. Pretorius, MRS Symp. Proc. 25 (1984) 25.

[13] R. Pretorius, Proceedings of the 11 th International Vacuum Congress and 7 th International Conference on Solid Surfaces, Cologne, West Germany, 25-29 September 1989, to be published.

[14] R. Hultgren, P.D. Desai, D.T. Hawkins, M. Gleiser and K.K. Kelley, Selected values of thermodynamic properties of binary alloys (American Society for Metals, Metals Park, $\mathrm{OH}, 1973$ ).

[15] A.M. Brown and M.F. Ashby, Acta Metall. 24 (1980) 1088.

[16] G. Tamman and Q.A. Monsuri, Z. Anorg. Chem. 126 (1923) 119. 